\title{
Opportunities and challenges of inland waterways transport in the southwest coastal belt of Nigeria
}

\author{
Owoputi Adetose Emmanuel $^{\text {a1 }}$, Paul I. Ifabiyi ${ }^{\mathrm{b}}$ and Akpudo U. Chijioke ${ }^{\mathrm{a}}$ \\ ${ }^{a}$ Department of Transport Management Technology, Federal University of Technology, Akure, Nigeria. \\ ${ }^{b}$ Department of Geography \& Environmental Management, University of Ilorin, Ilorin, Nigeria.
}

\begin{abstract}
Nigeria has 853 kilometers of coastline, 450 kilometers inland waterways and a sovereign right to 200 nautical miles exclusive economic zone. In spite of this, water transport has a share of $1.6 \%$ of Nigeria's domestic product. This study examines the opportunities and challenges of waterways transportation in the coastal area of Southwestern Nigeria. The specific objectives are to: (i) evaluate the potential of the area for Inland water transport development;

(ii); examine the contribution of inland waterways transport to passenger and freight movement, (iii) examine the impact of inland waterways transportation on socio-economic development; and (iv) evaluate the problems of inland waterways transportation in the area. Data were collected from both primary and secondary sources. Two types of questionnaires were administered in this study. A total of 415 copies of questionnaires (A) were administered to eight government agencies and 570 copies of questionnaires (B) were administered to residents. Both descriptive and inferential statistical methods were used. The descriptive methods employed are graphs, tables, charts, and central measures. The inferential analyses used in this study were factor analytical procedure, multiple regression methods and post hoc analysis. The study revealed that:- i, there are 48 river basins in the study area, with a combined basin area of $1,375 \mathrm{~km}^{2}, 873$ streams and a total stream length of 791.80 kilometers, drainage density of 1.73 , stream frequency of 1.58 and drainage intensity of 1.10 . These show that the potential of inland waterways transport is high; the report of ridership which was only available for Lagos state showed a progressive increase from 4.4 to 14.5 million between 2010 to 2014 . There are 318 open fiber taxis, while travel time range from 10 to 70 minutes. Major cargo are wet cargo, dry cargo, farm products, and fish. However, $10 \%$ of the cargo is contraband. Cargo is charged per kilo, size occupied, by value, and by distances. Duration of boats rent is one week to five weeks; the factors underlying the socio- economic impacts at the jetties vary from one jetty to the other. In Lagos, six factors explained $68.547 \%$ of the variance; in Ogun Jetties, five factors explained $78.9 \%$ of the variance, while in Ondo Jetties six factors explained $69.1 \%$ to the variance; the results of the analysis further showed that 4 major problems impacted on inland waterways development. These are: financial constraints, congestion at the jetties, insufficient jetty facility, and political influence. They altogether explained $92.02 \%$ of the variance in the explanation. The paper concludes that inland waterways have a high potential for transportation, but it is largely underutilized. The study recommended stronger policies and the need to encourage private- public participation in waterway transport development in the southwest coastal area of Nigeria.
\end{abstract}

Keywords: Coastal cities transportation, Economic variables, Infrastructure, Opportunities, Sustainable transport system

\section{Introduction}

Inland waterways transportation is one of the oldest economic and environmental sustainable modes of transportation for passengers and cargo; in some areas it is the only means of mobility and access to basic services. The sector encompasses vessels ranging from simple non-motorized boats to highly automated pushers, operating on waterways ranging from small tributaries to major rivers. Inland waterways play a vital role in economic development, especially in remote areas while the potentials opportunities for this sector depends considerably on the specific regional context such as geographical conditions, level of road development and socio-economic conditions. Inland waterways include all rivers, lakes, inland channels, canals deep enough for water bone traffic and protected tidal waters. The welfare of the remote rural areas of the inhabitants who are usually among the lowest of low income groups in the region. In the absence of river and other forms of inland waterways transport, many remote underprivileged communities would be inaccessible or too costly to service by other means.

Transportation, throughout history is the economic wealth and military power of the people or any Nation. Transport has been closely tied to efficient methods of transportation and movement of people and goods from one location to another. It has generated more increase

\footnotetext{
${ }^{1}$ Corresponding Author:

ORCID:

Email address: esoteda@yahoo.com, tokunifabiyi@yahoo.com

DOI: http://doi.org/10.4038/bhumi.v6i1.34
} 
in transport demand for social activities, exchange of products and services. Ogundana [1992] concluded that transportation provides access to natural resources and promotes trade, allowing the nation to accumulate wealth and power. Edward [2006] reported that transportation is a vital activity in moving both freight and passengers around the world. Transport is essential to the life of mankind.

As society and economic organization have become complex, so the need for transport has expanded and men have found it essential to use other forms of transport services. Ocean freight or inland water transport is probably the oldest and earliest means of transport used by man, in fact since the creation, water transportation have played a significant impact in feats which man have made to date. Indeed, there is no doubt that quite a substantial volume of freight and cargoes are handled daily in the inland waterways transport Industry. Ogundana [1973] viewed the ability to compete in a global economy as depending on maritime transport system as well as a vast array of supporting service activities. These supporting services include distribution based activities such as a multimodal and intermodal freight transport systems composed of modes, infrastructure and terminals. In addition, the regulation based activities are needed such as the customs procedures, tariffs, regulations and handling of documentation. He concluded that 'the quality, cost and efficiency of these services influence the trading environment as well as the overall costs linked with transport the international trade of goods. Ogunsanya [2000] explained that special consideration should be taken into account as logistical solutions for the inland waterways ports and Jetty in Nigeria have the following features:-

Usoro [2003] and Obed [2013] reported that despite the fact that Nigeria has about 3000 kilometres of inland waters, six major ports and ten crude oil terminals, and several inland ports in Onitsha, Oguta, Opobo, Lokoja, Baro, Jebba, Ayietoro, Epe, etc, in the year 2000, only 139 indigenous marine vessels (less than 6\%) were involved in this traffic with a cargo throughput of 441,031 tons (about 1\%. ) they concluded that indigenous shipping companies do not own any vessel for deep-sea trade and a few that participate operate the vessels on charter. Consequently, Igbokwe [2010] identifies some of the challenges and problems of enforcing the Cabotage Act to include:-

exclusion of Indigenous Shippers Association of Nigeria (ISAN) from ministerial consultation process in granting waivers; inadequate implementation and monitoring of inter-ministerial and inter-agency/inter-unit wrangling and uncooperative attitudes; high cost of enforcement and monitoring; lack of political will and determination; lack of confidence; and local / Foreign operators' dichotomy and several resolution of Cabotage disputes/ differences by the court.

Studies in Maritime Industry and inland waterways transport in Nigeria have been limited to river Niger and Benue. Comparatively, little studies have been done on inland waterways in the coastal belt of Nigeria and its implication on transport development. It is against this background therefore, that this work seeks to examine the opportunities and challenges of inland waterways on transport development in the coastal belt of Nigeria.

\subsection{Aim and objectives}

The focus of this research is to examine the opportunities and challenges of inland waterways Transportation and measures capable of developing and improving it in the western coastline of Nigeria. The specific objectives of this study include to:-

- Classify the pattern of freight movement in the southwest coastal belt of Nigeria;

- Examine the Impacts of waterway transportation on socio-economic development in the southwest coast of Nigeria;

- Examine the problems hindering its utilization and extent of freight transportation on the waterways; and

- Examine the prospect of inland waterway transportation in the coastal part of nation.

\subsection{Geography of the study area and location}

The study area for this research is the south west coast of Nigeria and coastal creeks of Lagos, Ogun and Ondo state coastal belt. It has many rivers that empty directly into the oceans. This found between latitude $410^{\prime}-620$ ' $\mathrm{N}$ and longitude $245^{\prime}-835^{\prime} \mathrm{E}$.

The project area falls within the southern part of Nigeria which is located between Latitude 6o 30 and Longitude 4030 and 5' $05 \mathrm{E}$ in the Southern part of Nigeria. The project area has boundary with Benin Republic in the West and Edo state in the East, the Atlantic Ocean in the South, the Yoruba's hill in the North. Generally, the topography rises from sea level to 15 meters elevation over a distance of 20 kilometre upland.

In the communities construction of roads are almost impossible because of the terrain, hence creeks and lagoons provide the only mode of transportation among the numerous fishing communities in the area. The coastwise movements between towns in different states are also possible between Lagos to Igbekoda in Ondo State. . There are various interstate movements for example, between Lagos -Epe - Ikorodu in Lagos and the Ilaje -Igbokoda, Ayetoro and ESE - Odo of Ondo State. 


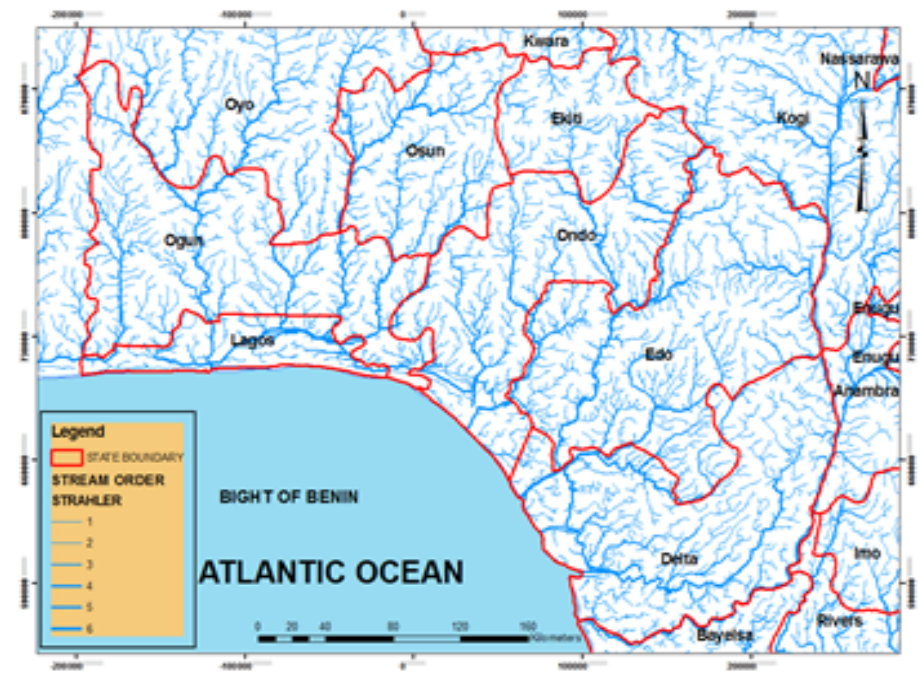

Figure 1: Study Area

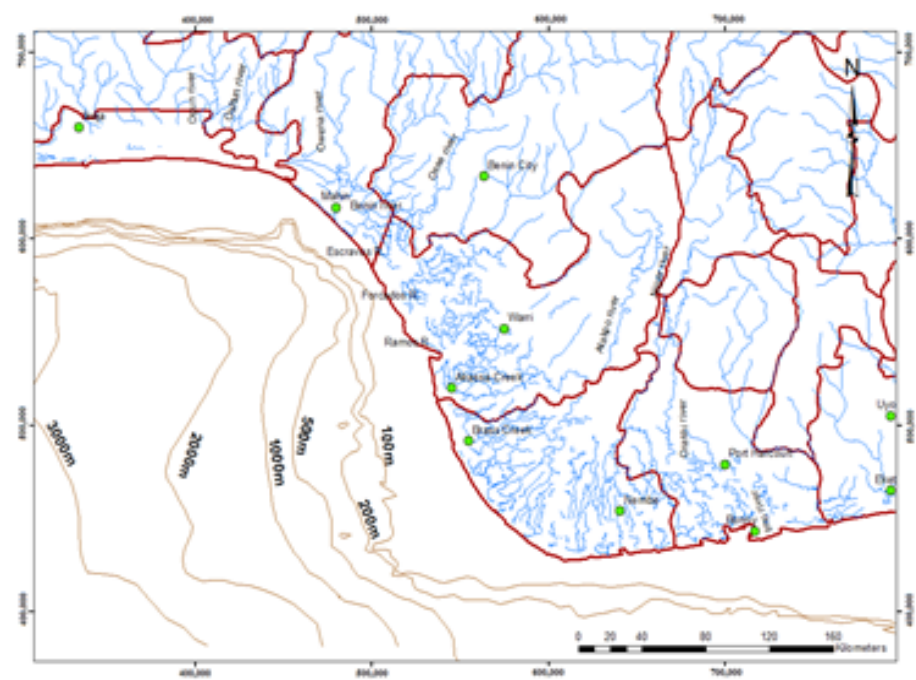

Figure 2: Bathy metric Characteristics

(Sources: Nwilo \& Badejo, 2006)

\section{Methods and materials}

Data were collected from both primary and secondary sources. Two types of questionnaires were administered in this study. Both descriptive and inferential statistical methods were used. The inferential methods of analyses are factor analytical procedure, multiple regression method.

The basic analysis above shows the influence on the water levels at different course of the water flow which indicated the depth of the water at a particular level and season. This coastline is found in three states, namely: Lagos, Ogun and Ondo States. The most southern point near Ilaje in the area of Ondo State is about $4^{0} \mathrm{~N}$ of Equator while the Northern boundary is approximately at $7^{0} \mathrm{~N}$. The characteristics of the coastal inland waterways of the southwest area of Nigeria are of drainage. The basic analysis below showed the influence on the water levels at different course of the water flow which indicated the depth of the water at a particular level and season. The basin linear morphometric properties of the rivers and stream along the coastal waterways of the study area that has impact on the level, depth and weight and length of the coast that influence the type of boat, vessel and ship that can be on the water at a particular time in the different area within different season of the year.

The Table 2 below shows the basin areal morphometric properties of the rivers and streams along the study area. It shows the total stream length and it drainage density. This account for the total stream length which has effect on the waterways and influence the transportation system, goods, persons, and services available in the study area. This act has an elevation of the coastal water level from Lagos State coastline to Ondo State coastline which is the study area.

Only few communities are accessible by road. Intercommunal mode of transportation is by boats (water). The high rainfall and river discharge during the rainy season combined with the low flat terrain and poorly drained soils result in extensive flooding and erosion. This has impact on the hydrological balance in the study area.

Inland Waterway Ridership: Although the 3 States under study are endeavored with inland water services. It is only the Lagos State that have recorded information on ridership, while Ogun and Ondo State are yet to develop their inland water resources and data base. The information for Lagos was not recorded until June 2010, while it was created by Law in January 2010, is presented in Table 3. In 2010 between the month of June and December, a total ridership of $4,375,112$ was recorded in Lagos State waterways transportation while in 2011 between January and December a total ridership of $14,481,240$ while in the same period in 2012 the ridership was 13,487,95. In year 2013 there was an increase in the ridership of coastal inland waterways service of Lagos State to 19,109,514 and 2014 recorded the highest in the five years data of ridership with $21,768,813$ riders in Lagos State inland coastal ways which has reduced road traffic.

\section{Factor Analysis: Factors affecting the facilities at the Jetties}

Question 16-25, except question 20, assess the jetty facilities. The respondents' ratings are used to extract factors affecting the facilities at the jetties: The principal component method was used for the extraction and three factors were extracted using SPSS.

Factor 1 has high positive loadings on the following variable: Jetty underutilization (.898), politics (.660) and finance (.884). Utility of Jetty (-864) loads highly, almost at the same level with underutilization of Jetty, but negatively and counseling out the latter. Factor 1 can therefore be referred to as effect of government policies. 
Table 1: Basin Linear Morphometric properties. (A uthor's Field computation Survey, 2015)

\begin{tabular}{|c|c|c|c|c|c|c|c|c|c|c|c|}
\hline \multirow[b]{2}{*}{ No } & \multirow[b]{2}{*}{ Basin } & \multirow{2}{*}{$\begin{array}{c}\text { Basin } \\
\text { Area }\end{array}$} & \multicolumn{4}{|c|}{ Stream Order } & \multirow{2}{*}{$\begin{array}{l}\text { Total } \\
\text { Strea } \\
\text { m No }\end{array}$} & \multicolumn{4}{|c|}{ Stream Length } \\
\hline & & & 1 & 2 & 3 & 4 & & I & ii & iii & Iv \\
\hline 1 & Ibasa & 371.64 & 19 & 24 & 3 & 0 & 46 & 45.38 & 45.41 & 5.49 & 0 \\
\hline 2 & Ajah & 296.73 & 13 & 9 & 4 & 0 & 26 & 30.95 & 27.91 & 14.28 & 0 \\
\hline 3 & Agaja & 1020.21 & 50 & 27 & 26 & 24 & 127 & 118.75 & 64.61 & 65.01 & 16.58 \\
\hline 4 & Odo-nla & 143.85 & 69 & 24 & 19 & 0 & 112 & 150.43 & 68.81 & 69.54 & 0 \\
\hline 5 & Irewe & 1564.24 & 75 & 23 & 50 & 3 & 151 & 171.74 & 100.64 & 139.88 & 8.41 \\
\hline 6 & Igbokoda & 1513.31 & 71 & 37 & 23 & 19 & 150 & 239.93 & 91.76 & 40.89 & 49.21 \\
\hline 7 & Alawo & 39.22 & 98 & 50 & 4 & 0 & 152 & 194.83 & 112.97 & 17.59 & 0 \\
\hline 8 & Oworo & 29.19 & 11 & 6 & 0 & 0 & 17 & 43.51 & 16.25 & 0 & 0 \\
\hline 9 & Ijegun-Egba & 13.32 & 59 & 29 & 1 & 0 & 89 & 67.87 & 56.01 & 7.05 & 0 \\
\hline 10 & Awoye & 68.59 & 70 & 39 & 1 & 0 & 110 & 127.05 & 94.32 & 1.71 & 0 \\
\hline 11 & Aiyetoro & 2912.46 & 190 & 2 & 49 & 51 & 292 & 431.02 & 172.08 & 152.94 & 72.24 \\
\hline
\end{tabular}

Table 2: Basin Areal Morphometric properties. (Author's computation Survey, 2015)

\begin{tabular}{|r|l|r|r|r|r|r|r|}
\hline No & \multicolumn{1}{|c|}{ Basin } & $\begin{array}{c}\text { Total- } \\
\text { Strm } \\
\text { Length }\end{array}$ & \multicolumn{1}{|c|}{ MSL } & $\begin{array}{c}\text { Drainage Densi- } \\
\text { ty }\end{array}$ & $\begin{array}{c}\text { Drainage Inten- } \\
\text { sity /River }\end{array}$ & LOF & StrFreq \\
\hline 1 & Olokola & 96.28 & 2.093043 & 3.8600223 & 0.4777732 & 0.518132 & 8.079194 \\
\hline 2 & Itegbin & 73.14 & 2.813077 & 4.0570176 & 0.3554826 & 0.492973 & 11.4127 \\
\hline 3 & Esofin & 264.95 & 2.08622 & 3.8505856 & 0.4793357 & 0.519402 & 8.033171 \\
\hline 4 & Oluwa & 288.78 & 2.578393 & 0.4981469 & 0.3878385 & 4.01488 & 1.284418 \\
\hline 5 & Badore & 420.67 & 2.785894 & 3.7184498 & 0.3589512 & 0.537859 & 10.35921 \\
\hline 6 & Araromi & 421.79 & 2.811933 & 3.5878297 & 0.3556272 & 0.55744 & 10.08874 \\
\hline 7 & Ijede & 325.39 & 2.140724 & 0.1205339 & 0.4671318 & 16.59285 & 0.25803 \\
\hline 8 & $\begin{array}{l}\text { Egba water- } \\
\text { side }\end{array}$ & 59.76 & 3.515294 & 0.4884285 & 0.2844712 & 4.094765 & 1.71697 \\
\hline 9 & Ugbe & 130.93 & 1.471124 & 0.1017466 & 0.6797525 & 19.65667 & 0.149682 \\
\hline 10 & Ikorodu & 223.08 & 2.028 & 0.3074719 & 0.4930966 & 6.504659 & 0.623553 \\
\hline 11 & Ogogoro & 828.28 & 2.836575 & 3.5162761 & 0.3525378 & 0.568784 & 9.974182 \\
\hline
\end{tabular}

Factor 2 loads positively and highly on the following variables: Jetty infrastructure (.654), Jetty facilities (.790), Accessibility to infrastructural facilities by users (.629) and Jetty equipment (.605). This factor can be referred to as facility factors.

Factor 3 loads highly only on skilled labour (.849), it is also fairly high on equipment (.402) and politics (.437). This factor may be call jetty management.

Extraction Method: Principal Component Analysis. Rotation Method: Quart Imax with Kaiser Normalization. a Rotation converged in 5 iterations.
The factor scores were obtained and a comparison is made among the various jetties using Analysis of Variance.

To examine the opportunities of inland waterways on socio-economic development, seventeen (17) variables were considered which were subsequently reduced to six (6) orthogonal variables. Variables where loadings greater than 0.70 were selected as defining variables. The results of the factor analysis after vari-max rotation show some underlying factors. These six (b) factors altogether gives $68.54 \%$ in the explanation of the variation on the impacts of inland waterways on socioeconomic development of Lagos coastal area. (Table 5) 
Table 3: Ridership in Lagos State.

(Source: Lagos State Waterways Transport Authority, 2015)

\begin{tabular}{|c|c|c|c|c|c|c|c|}
\hline $\begin{array}{l}\text { Month } \\
\text { s }\end{array}$ & 2010 & 2011 & 2012 & 2013 & 2014 & TOTAL & MEAN \\
\hline Jan & \multirow{5}{*}{$\begin{array}{l}\text { No data } \\
\text { record }\end{array}$} & 987,256 & 481,745 & $1,103,567$ & $1,798,343$ & $4,370,911$ & $1,092,728$ \\
\hline Feb & & $1,210,046$ & 892456 & $1,471,325$ & $1,794,421$ & $5,368,248$ & $1,342,062$ \\
\hline Mar & & $1,327,523$ & $1,212,768$ & $1,545,183$ & $1,794,848$ & $5,880,322$ & $1,470,081$ \\
\hline Apr & & $1,135,810$ & $1,560,182$ & $1,671,225$ & $1,789,212$ & $6,156,429$ & $1,539,107$ \\
\hline May & & $1,269,754$ & $1,238,905$ & $1,852,653$ & $1,790,899$ & $6,152,211$ & $1,538,053$ \\
\hline Jun & 495,010 & $1,255,641$ & $1,269,754$ & $1,862,767$ & $1,788,315$ & $6,671,487$ & $1,334,297$ \\
\hline Jul & 475,024 & 978,098 & $1,729,712$ & $1,788,370$ & $1,787,478$ & $6,758,682$ & $1,351,736$ \\
\hline Aug & 525,078 & $1,210,049$ & $1,135,856$ & $1,737,157$ & $1,788,487$ & $6,396,627$ & $1,279,325$ \\
\hline Sep & 568,484 & $1,327,523$ & $1,328,002$ & $1,711,285$ & $1,788,036$ & $6,723,330$ & $1,344,666$ \\
\hline Oct & 648,984 & $1,135,021$ & $1,355,769$ & $1,733,544$ & $1,879,098$ & $6,752,416$ & $1,350,483$ \\
\hline Nov & 787,269 & $1,318,372$ & $1,327,984$ & $1,365,803$ & $1,867,045$ & $6,666,473$ & $1,333,295$ \\
\hline Dec & 875,263 & $1,326,147$ & $1,327,863$ & $1,366,635$ & $1,902,631$ & $6,798,539$ & $1,359,708$ \\
\hline
\end{tabular}

Table 4: Components of Assessment of facilities at the Jetties. (Source: Author's computation, 2015)

\begin{tabular}{|l|r|r|r|}
\hline \multirow{2}{*}{\multicolumn{1}{|c|}{ Factors }} & \multicolumn{3}{|c|}{ Component } \\
\cline { 2 - 4 } & $\mathbf{1}$ & \multicolumn{1}{c|}{$\mathbf{2}$} & \multicolumn{1}{c|}{$\mathbf{3}$} \\
\hline Jetty Inf. & -.344 & .654 & -024 \\
\hline Utility & -.864 & .170 & .219 \\
\hline Und. Utility & .898 & .003 & -065 \\
\hline Jetty facilities & .120 & .790 & -280 \\
\hline Acc. Facilities & -.042 & .629 & .331 \\
\hline Politics & .660 & -.022 & .437 \\
\hline Equipment & -.175 & .605 & .402 \\
\hline S labor & .076 & .127 & .849 \\
\hline Finance & .884 & -.102 & .123 \\
\hline
\end{tabular}

Factor I: Waterways Utilization has the highest number of loadings, with high loadings on waterways underutilized control variables. This factor contributed $16.55 \%$ of explanation to the variance on the impacts of inland waterways on socioeconomic development and has an Eigen value of 2.97. In other words, the utilization of inland waterways transport is the most important factor that determines the variation in the opportunities of inland waterways on socioeconomic development in Lagos coastal area.

Factor II: Monthly Income has an Eigen value of 2.188 and contributed $12.15 \%$ to the variance on the opportunities of inland waterways on socioeconomic development of Lagos coastal area. It has the highest loading on average monthly income. This suggested that monthly income is the second most important factor that explains the variation in socioeconomic development that can be attributed to inland waterways in the study area.
Factor III: Sufficiency of Terminal facilities is a third factor that determines the variation in socioeconomic development that can be attributed to inland waterways has the highest loading on sufficient Jetties facilities. This factor has an Eigen value of 2.078 and explained $11.55 \%$ of the variance in socioeconomic development of the coastal area of Lagos. This can be attributed to the impact of inland waterways activities in this area.

Factor IV: The fourth factor with the highest loading is Educational Status with an Eigen value of 1.908 and which explained $10.60 \%$ of the total variance in the socioeconomic development of the Lagos coastal area that can be attributed to inland waterways. In other words, educational status is the fourth factor that determines the variation in socioeconomic development that is attributed to inland waterways usage in Lagos coastal area.

Factor V: Occupational Status has an Eigen value of 1.659 and contributed $9.22 \%$ to the variance in the socioeconomic development of Lagos coastal area. This

suggested that the occupational status of the people of the Lagos coastal area is the fifth factor that explained the variation in the socioeconomic development that can be attributed to inland waterways usage.

Factor VI: Terminal / Jetties Facilities is the sixth factor that determines the variation in socioeconomic development that can be attributed to inland waterways has the highest loading on terminal/Jetties facilities assessment. This factor has an Eigen value of 1.526 and explained $8.48 \%$ of the variance in socioeconomic development of the coastal area of Lagos that can be attributed to inland waterways.

To examine the opportunities of inland waterways on socioeconomic development, eighteen (18) variables were collected which were subsequently reduced to five 
Table 5: Opportunities of Inland Waterways on Socioeconomic Development of Lagos Coastal Area (Rotated Component Ma (Author's Data Analysis, 2015)

\begin{tabular}{|c|c|c|c|c|c|c|}
\hline Factor defining Variable & $\begin{array}{c}\text { Waterways } \\
\text { Under Uti- } \\
\text { lized }\end{array}$ & $\begin{array}{c}\text { Average } \\
\text { Monthly In- } \\
\text { come }\end{array}$ & $\begin{array}{c}\text { Jetties Fa- } \\
\text { cilities }\end{array}$ & $\begin{array}{l}\text { Education- } \\
\text { al Status }\end{array}$ & $\begin{array}{l}\text { Occupa- } \\
\text { tion }\end{array}$ & $\begin{array}{l}\text { Terminal In- } \\
\text { frastructure }\end{array}$ \\
\hline Factor Description & $\begin{array}{l}\text { Waterways } \\
\text { Utilization }\end{array}$ & $\begin{array}{l}\text { Monthly In- } \\
\text { come }\end{array}$ & $\begin{array}{l}\text { Sufficiency } \\
\text { of Termi- } \\
\text { nal Facili- } \\
\text { ties }\end{array}$ & $\begin{array}{l}\text { Education- } \\
\text { al Status }\end{array}$ & $\begin{array}{c}\text { Occupa- } \\
\text { tional Sta- } \\
\text { tus }\end{array}$ & $\begin{array}{c}\text { Terminal/ } \\
\text { Jetties Infra- } \\
\text { structure as- } \\
\text { sessment }\end{array}$ \\
\hline Total Eigen value & 2.979 & 2.188 & 2.078 & 1.908 & 1.659 & 1.526 \\
\hline$\%$ Variance & 16.55 & 12.153 & 11.55 & 10.6 & 9.217 & 8.479 \\
\hline$\%$ Cumulative variance & 16.55 & 28.702 & 40.25 & 50.85 & 60.07 & 68.547 \\
\hline
\end{tabular}

Table 6: Opportunities of Inland Waterways on Socioeconomic Development of Ogun Coastal Area (Rotated Component Matrix ${ }^{\mathrm{a}}$ ). (Author's Data Analysis, 2015)

\begin{tabular}{|l|r|r|r|r|r|}
\hline \multicolumn{1}{|c|}{ Factor defining Variable } & $\begin{array}{c}\text { Sufficient Jetties } \\
\text { Facilities }\end{array}$ & $\begin{array}{c}\text { Adequate Termi- } \\
\text { nal Facilities }\end{array}$ & $\begin{array}{c}\text { Port Functional } \\
\text { Facilities }\end{array}$ & $\begin{array}{c}\text { Facilities Easily } \\
\text { Accessed }\end{array}$ & $\begin{array}{c}\text { Political } \\
\text { Influence }\end{array}$ \\
\hline Factor Description & $\begin{array}{c}\text { Sufficiency of } \\
\text { Jetties Facilities }\end{array}$ & $\begin{array}{c}\text { Adequacy of } \\
\text { Terminal Facili- } \\
\text { ties }\end{array}$ & $\begin{array}{c}\text { Functionality of } \\
\text { Port Facilities }\end{array}$ & $\begin{array}{c}\text { Users Ease of } \\
\text { Facility Accessi- } \\
\text { bility }\end{array}$ & $\begin{array}{c}\text { Political } \\
\text { Influence }\end{array}$ \\
\hline Total Eigen value & 4.144 & 3.186 & 2.862 & 2.244 & 1.771 \\
\hline$\%$ Variance & 23.02 & 23.02 & 40.722 & 56.62 & 69.89 \\
\hline Cumulative variance & 17.701 & 78.93 \\
\hline
\end{tabular}

(5) orthogonal variables. Variables with loadings greater than 0.70 were selected as defining variables. The results of the factor analysis after vari-max rotation show some underlying factors. These five (5) factors altogether gives $78.93 \%$ in the explanation of the variation on the impacts of inland waterways on socioeconomic development of Ogun State coastal area (Table 6).

Eighteen (18) variables were entered into factor analysis, which were subsequently reduced to six (6) orthogonal variables. Variables with loadings greater than 0.70 were selected as defining variables. The results of the factor analysis after vari-max rotation show some underlying factors. These six factors altogether gives $69.118 \%$ in the explanation of the variation on the impacts of inland waterways on socioeconomic development of Ondo state coastal area (Table 7).

This factor has an Eigen value of 2.038 and explained $11.32 \%$ of the variance in socio economic development of the coastal area of Ondo State that can be attributed to inland Waterways. In other words, the third factor that determines the variation in the socioeconomic Development of Ondo State coastal area is based on the terminal/jetties facilities assessment Socio-economic development of Ondo State coastal area is based on the terminal/jetties facilities Assessment of the people in this area.

\section{Conclusions and recommendations}

The analysis and research finding of the opportunities and challenges of Inland waterways on transport development in the coastal belt of Nigeria has yield some important results from which implications and conclusion were drawn. The study established the characteristics of coastal Inland waterways and freights in the study area 'southwest coastal belt of Nigeria and it impacts on Coastal Cities. The research identified the factors that influenced the usage, operation and movement of goods and services along the coastal Cities waterways in the study area. It has also examined and evaluated the social economic opportunities in coastal Inland waterways of southwest Coastal Cities of Nigeria, which shows that inland waterways has high potentials.

The study assessed the challenges and hindrances of the maximum-utilization of the waterways transportation in the Coastal Cities and it impact on safety, security and economic development. The research study examined various usage of the waterways and it contribution to the 
Table 7: Opportunities of Inland Waterways on Socioeconomic Development of Ondo State Coastal Area (Rotated Component Matrix ${ }^{\mathrm{a}}$ ). (Author's Data Analysis, 2015)

\begin{tabular}{|c|c|c|c|c|c|c|}
\hline Factor defining Variable & $\begin{array}{c}\text { Waterwa } \\
\text { ys Under } \\
\text { Utilized }\end{array}$ & $\begin{array}{l}\text { Political } \\
\text { Influence }\end{array}$ & $\begin{array}{c}\text { Terminal } \\
\text { Infrastructur } \\
\mathrm{e}\end{array}$ & $\begin{array}{l}\text { Average } \\
\text { Monthly } \\
\text { Income }\end{array}$ & $\begin{array}{l}\text { Occupati } \\
\text { on }\end{array}$ & $\begin{array}{c}\text { Port } \\
\text { Functional } \\
\text { Facilities }\end{array}$ \\
\hline Factor Description & $\begin{array}{c}\text { Waterwa } \\
\text { ys } \\
\text { Utilizatio } \\
\text { n }\end{array}$ & $\begin{array}{c}\text { Political } \\
\text { Influence }\end{array}$ & $\begin{array}{c}\text { Terminal/ } \\
\text { Jetties } \\
\text { Infrastructur } \\
\text { e Assessment }\end{array}$ & $\begin{array}{l}\text { Monthly } \\
\text { Income }\end{array}$ & $\begin{array}{l}\text { Occupati } \\
\text { onal } \\
\text { Status }\end{array}$ & $\begin{array}{c}\text { Functionality } \\
\text { of Port } \\
\text { Facilities }\end{array}$ \\
\hline Total Eigen value & 3.523 & 2.063 & 2.038 & 1.687 & 1.626 & 1.504 \\
\hline$\%$ Variance & 19.57 & 11.46 & 11.324 & 9.373 & 9.032 & 8.355 \\
\hline$\%$ Cumulative variance & 19.57 & 31.03 & 42.358 & 51.73 & 60.76 & 69.118 \\
\hline
\end{tabular}

communities and the nation at large. It also looks at various activities with the Local governments of each States along the coastal Inland water ways of the study area activities. Detailed data were examined concerning the commodities that flow between Jetties and terminal in the study area and the vessels that carry them. Container traffic was analyzed separately from all other types due to the unique type of infrastructure and equipment employed in the container trade.

The researcher also identified possible triggers that might cause an abrupt increase in Inland waterways transportation activity in the Coastal Cities. Researcher examined the potentials role of the southwest inter coastal waterways in handling coastwise trade and the possibility of developing a viable ocean going coastwise domestic trade in the Nigeria coastal Cities.

\subsection{Conclusion}

Considering the many factors that limit our nation today, the untapped treasures and huge economic opportunities abound in the maritime/coastal, and inland waterways (rivers) and tributaries that transverse the entire landscape of Nigeria Coastal Cities, with over 50 rivers and coastal water are of potential benefits to our people, if properly harnessed. Coastal inland water ways can add value to the economy in the Coastal Cities as mass transportation, international trade, agriculture, human capacity development, tourism and hospitality, mineral exploration, as well as provide the much sought after employment, to mention but a few. And lastly with the development of Coastal Cities, the inland waterways container port / jetties, investment opportunities are imminent in the area of haulage, ferry services, boat movements.

Fabrication and assemblage, warehousing and storage facility services, heavy material handling services, dredging services, dockyard facility provision, protocol and safety management services, hydrographical survey catering services, towage stevedoring consultancy and many others. The silent potential revolution of coastal Cities, inland water, maritime services and resources left to fallow will be brought back to live and both state and federal government with the communities would enjoy much of the awaited economic change that will take place. Huge vacuum is for both private participation and public-private partnership. It is high time every businessman start to think to investment in the Coastal Cities inland waterway Development.

The needed innovations infrastructural equipment's in the Coastal Cities area are: (a) Port, Jetties, cannel and inland waterways, modernization strategy to accommodate large vessels for future operations (b) Identifies possible options for implementing the vision (c) The availability of multi-modal infrastructure for port, Jetty and vessels operation equipment in the Coastal Cities of Nigeria inland waterways.

\subsection{Recommendation and contribution to knowledge}

As a maritime nation our economic prosperity is directly linked to our investments in navigation infrastructure. Just as current generations benefit from investments made in the past, the ability of future generations to prosper and grow will depend on infrastructure investment decisions made today on Coastal Cities. A globally competitive maritime/inland water ways transportation system for the 21 st century will have these characteristics.

a. Environmentally compatible development, infrastructure on the Coastal Cities,

b. High - performance and reliable marine channels, turning basins and other related navigation infrastructure that are maintained to sustain the Coastal Cities,

c. Navigation jetties that are planned constructed and maintained for safe, reliable and efficient freight movement in the Coastal Cities of Nigeria.

d. Capital investments in locks for replacement, major rehabilitation or expanded capacity that are established through a capital investment plan that identifies and prioritizes on a system basis that can sustain the growth of Coastal Cities,

e. An identified mechanism for the financing of operations, maintenance and capacity improvements of Coastal Cities environment,

f. Constriction of terminal building and storage 
facilities of goods for Shipment

g. Construction of passenger facilities at ports, Jetties for contort and safety of inland waterway for users and operators in the Coastal Cities.

The management, maintenance, development and restoration of the coastal cities navigable waterways system throughout the coastal Cities are: recreational trade, goods and services distribution, with low cost of operation purposes. The need for strategic plan for the waterways that will include the local communities, that many Opportunities for development of the Coastal Cities waterways for economic and transportation services activities along the waterways corridors including; Trade, personnel movement, tourism, freight forwarding, all related projects should take into consideration potential adverse effects on the heritage of the Coastal Cities waterways.

Policies and guidelines are needed to ensure sustainable developments in the coastal Cities inland waterways management.
The voluntary sector should be encouraged to continue its involvement in waterways development of the Coastal cities and non-governmental organizations should be recognized as important partners by the new Coastal Cities Development body.

Funding has to be made available for tourism projects, jetties warehousing, loading and offloading equipment to encourage break bulk activity of vessels at the jetties to reduce congestion at the port of Coastal Cities.

Developing and creating integrated inland waterways holidays, water-based leisure activities to promote tourism and interrelationship along communities, users, traders and investors for economic growth of Coastal Cities.

The coastal Cities inland waterways transportation should have wider implication on job creation, revenue generating, investment and industrial development with local and recreational amenity value increase.

\section{References}

Ogundana B. (1992) “The Measurement of port productivity in Nigeria, in Onakomaiya et al

Edward J. Bordi [2006] The supply chain and the economy in management of Transportation 'International student edition' Publisher Thomason by South Western

Ogundana B. (1973) Problems and prospects of river transport in Nigeria. The Nigeria Journal of economic and social study, vol, 15. Pp375-390

Ogunsanya, A A. (2000) "Port Development" in Falola T. and Olarewaju S. A. (eds) Transport System in Nigeria. Maxwell School of Citizenship and Public Affairs Syrncuse University

Usoro. K. E. (2003) 'Basic Requirements for movement of cargo by sea' in Nigeria Shipping Annual Abstract

Obed, Ndikom B. C ( 2013 ) A critical assessment of the Inland waterways operations and management on the development of the Nigeria maritime Industry, Greener Journal of environmental management and public safety

Igbokwe (2010) Toward achieving effective seaport freight management, A presentation at a seminar on port terminals and logistics. Organized Admiralty Resources Services, Lagos June 2010 